\title{
Introduction
}

\section{Durkheim's Contribution to the Debate on the Separation of Church and State in 1905}

\author{
W. S. F. Pickering
}

\begin{abstract}
This is the first English translation of Durkheim's contribution to an important debate on the separation of church and state (1905) - in the course of which he remarked, to an outburst from those present, that 'From a sociological point of view, the Church is a monstrosity'. The translation comes with an introduction and editorial notes by W. S. F. Pickering, explaining the background to the debate, identifying the participants, and recommending some of the many books and articles on the issue.
\end{abstract}

Keywords: Durkheim; church; state; monarchy; democracy; France

The only evidence we have about Durkheim's attitude towards the law of 1905 for the Séparation des Eglises et de l'Etat comes from his contributions to two colloquia held in May 1905. Even then the subjects under discussion were not about the proposed law in general but on specific topics set by the chairman of the colloques.

The two meetings that Durkheim attended were part of nine such gatherings held in Paris between January and May and were organized by Paul Desjardins (1859-1940). He was a somewhat extraordinary figure. He was an agnostic and a member of the Ligue des Droits de l'Homme which, at the fin de siècle had a membership of around 45,000, yet at the same time had a strong desire to reconcile Catholics with Free Thinkers - a mighty task indeed! To that end he organized meetings for discussion in Paris to which were invited scholars and others, including philosophers, historians, lawyers, businessmen, as well as Catholic and Protestant clergy. The proceedings were published in a journal of the same name as the group, Libres entretiens. The first publications that originated from the gatherings were entitled 'Sur la séparation des églises et de l'état'. From what Desjardins wrote in the introduction to the publications he appears to have been a very friendly, relaxed person, who wanted the gatherings to be as informal as 
possible. The discussions deliberately avoided the question of religious doctrines and rites: consequently the sessions dealt only with matters of property and organization. It should be noted that the meetings emerged from the Union pour la Verité. The Union had been founded a year or so before the discussions and was the successor of the Union pour l'Action Morale that had been formed in 1892. Desjardins was a college and 1ycée teacher, a writer and a member of the Institute. He organized conferences elsewhere in France, including the Abbey of Pontigny, where he died. One of his books Catholicisme et critique: réflexions d'un profane sur l'Affaire Loisy caused a considerable stir in its criticism of the Church.

This is no occasion to attempt to refer in any comprehensive way to the events that led to the passing of the Law of $1905 .{ }^{1}$ It was eventually passed on 9 December, promulgated on 11 December and came into effect about two years later. One might state in the briefest of summaries that the Law was the legal triumph of anticlericalist factions in abolishing Napoleon's Concordat of 1801 . This early pragmatic settlement between France and the Holy See pleased neither of the extremes - the firm supporters of Papacy on the one hand, and the Free Thinkers, Free Masons and socialists etc., on the other, who held that the Concordat gave too much power to the Church. The Law was the final triumph of the anticlericals in the long running battle to limit the power of the Church in France.

Apart from one explosive remark about the sociological nature of the Catholic Church, Durkheim's contributions were very balanced, considering his mild atheism. Indeed he showed himself somewhat conservative about the future of Church compared with certain Liberal Catholic speakers who welcomed the possible introduction of democratic principles into the Church - principles that would come about as a result of the passing of the Law.

W. S. F. Pickering is the founder of The British Centre for Durkheimian Studies, the University of Oxford. His many publications include Durkheim's Sociology of Religion (1984), and he is co-editor, with Massimo Rosati, of a forthcoming collection, Suffering and Evil: the Durkheimian Legacy (2007). In recognition of his contributions to the field, the French government awarded him in 2007 with the honour of the Ordre des palmes académiques. E-mail: william.pickering@anthropology.oxford.ac.uk

\section{Note}

1. Of the many books and articles that cover the Law, those that are recommended are listed as the Recommended Reading list following the Reference section. 


\section{Reference}

Durkheim, E. 1905e Contribution to a debate: 'Sur la séparation des églises et de l'état', in Libres entretiens, $1^{\mathrm{e}}$ série: $369-371$, 496-500; reprinted in 1975b Textes, vol. 2, Paris: Minuit: 165-169.

\section{Recommended Reading List}

Dansette, A. 1961 Religious History of Modern France, volume 2, Under The Third Republic, London: Nelson.

Langlois, C. 1996 'Catholics and Seculars', in P. Nora, ed., Realms of Memory, volume 1, Conflicts and Divisions, New York: Columbia University Press: 109-143.

Mayeur, J-M. 1966 La séparation des églises et de l'état, Paris: Julliard.

McManners, J. 1972 Church and State in France 1870-1914, London: Society for Promoting Christian Knowledge.

Phillips, C. S. 1936 The Church in France, 1848-1907, London: Society for Promoting Christian Knowledge.

Schiappa, J-M., ed. 2005 1905! La loi de séparation des églises et de l'état, Paris: Editions Syllepse.

Zarka, Y. V., ed. 2005 Faut-il réviser la loi de 1905? Paris: PUF. 